\title{
Forest Management Cooperatives and Their Development Under Uncertain Conditions: A Comprehensive Analysis Using an Actor-Centered Institutionalism Approach
}

\author{
Matthias Sonnhoff ${ }^{1}$ D $\cdot$ Andy Selter ${ }^{1} \cdot$ Daniela Kleinschmit $^{1} \cdot$ Ulrich Schraml $^{1}$
}

Accepted: 23 December 2020 / Published online: 7 January 2021

(c) The Author(s) 2021

\begin{abstract}
The change in forest ownership structures, the resulting fragmentation of forest properties and restitution processes have led to the emergence of organizations in Europe that are able to deal with these challenges. Changes in the timber selling process due to decisions of the German Federal Competition Authority have led first to uncertain conditions for forest management cooperatives (FMCs) and their members in the federal state of Baden-Wuerttemberg. In the course of this change, some FMCs have questioned their status quo while others have evolved under uncertain conditions. This paper aims to provide an overview of factors determining the further development of forest management cooperatives under uncertain conditions following the categories of actor-centered institutionalism (ACI). To be able to conduct a comprehensive political analysis of the changes taking place in the timber selling process, the ACI approach is used in conjunction with path dependency as the theoretical framework for this paper. Methodologically, it is based on a qualitative analysis of field protocols from four regional conferences in Baden-Wuerttemberg, Germany, involving a total of 140 participants in 2017. The results highlight that individual actors, the economic and social capabilities of FMCs, the existing constellations and interactions determine further developments under uncertainty. Legal certainty and in some cases the withdrawal of the state determine positively the dealing with uncertain situations. Foresters and their direction essentially determine the development. Furthermore, FMCs highlight that the cooperation with municipal foresters has a positive impact that will help deal with uncertainty in the future. A clear interest of cooperation and long-standing relationships also determine further developments under uncertain conditions.
\end{abstract}

Matthias Sonnhoff

matthias.sonnhoff@ifp.uni-freiburg.de

1 Albert-Ludwigs-Universitat Freiburg Freiburg I.Br, Baden-Württemberg, Germany 


\section{Introduction}

In Europe, forest management faces economic and societal challenges resulting from the fragmentation of forest property, due to changes in the ownership structure, restitution processes, in which small and large forest areas were returned to private owners, and the need for reforestation (Angelova et al. 2009; Campbell and Kittredge 1996; Hogl et al. 2005; Hugosson and Ingemarson 2004; Kittredge 2005). These factors have prompted governments and foresters to develop organizations based on cooperation to overcome these challenges (Kittredge 2005; Ripatti and Järveläinen 1997). In Germany and other countries, these organizations, forest management cooperatives (FMCs), were established to overcome forest fragmentation, support private and municipal forest owners in forest related management questions and to sell timber (Kittredge 2005; Oesten and Roeder 2002; Wippel 2014).

Forest management cooperatives in the German federal state of Baden-Wuerttemberg are facing particular circumstances due to changes in the timber selling process. The Federal Competition Authority in Germany decided in 2008 that timber selling for private and municipal forest owners could no longer be handled by the state forest administration as had been the case for more than 70 years (Bundeskartellamt 2008; Hasel 1985). The federal state (24\% of forest land) is nowadays only allowed to sell timber of areas owned by the state itself. Private (36\% of forest land) and municipal forest owners (40\% of forest land) have to sell their timber in cooperation with timber selling organizations that are not part of the state forest administration, e.g. FMCs. Through the dissolution of the state support structures (Wippel 2011) and the withdrawal of the state in the timber selling process for private and municipal forest owners, the majority of forest management cooperatives faced circumstances that they had not previously dealt with. In response to traditional problems such as fragmentation (the average size of forest land is smaller than 2 ha) and changes in the ownership structure and due to the new situation in the timber selling process and the needs arising from it, forest management cooperatives have to evolve under uncertain conditions (Selter et al. 2013; Wippel 2014).

FMCs tend to be market-oriented and have the subjects of economic analyses. Both qualitative and quantitative methods have examined developments that highlight strategic orientations and activity fields, e.g. increased support for timber selling services or support for management tasks and requirements, under country-specific conditions (Kronholm 2016; Leinert 1996; Moog and Borchert 1999; Ottisch 2001; Petkau 2007, 2008; Schaffner and Suda 1999; Suda et al. 2009; Suda and Warkotsch 2002). According to Kajanus et al. (2019; Glück et al. 2010; Kronholm 2016; Rapp 2000; Sarvašová et al. 2014; Selter et al. 2009; Schraml 2005, 2012; Petkau 2007), the further development of FMCs is determined by the requirements of private forest owners. These characteristics and preferences of forest owners were analyzed in detail (i.e. Feil et al. 2018; Ficko et al. 2019; Hogl et al. 2005; Ingemarson et al. 2006; Kuuluvainen et al. 2014; Lawrence et al. 2020; Matilainen et al. 2019; Schraml and Härdter will introduce the 
theoretical2002). For FMCs, the confidence of forest owners is essential when aiming to expand their membership structures to strengthen their market position, as new members decide to cooperate and participate depending on confidence (Kittredge 2005; Petkau 2008; Schraml 2003; Schraml and Selter 2011; Schurr 2006). Sarvašová et al. (2014) highlight, that besides the economic opportunities mentioned above, advice and education opportunities for members and the preparation of information for the members are fields of activity in which further development of FMCs can take place. Padgee et al. (2006) further emphasizes that clearly defined property boundaries, institutions, incentives and interest, financial and human resource support, physical features, community features, level of participation, degree of decentralization and the technology and market influence are relevant for the success of community forest management and thus also for the further development of FMCs. In addition to the economic and forest owner based factors described above other studies highlight that governmental framework conditions, e.g. forest subsidies, influence the development of FMCs (Sarvašová et al. 2014; Selter et al. 2013; Suda et al. 2009). These are used to implement governmental economic control instruments, which almost exclusively have the aim to improve timber production (Gießen et al. 2013). Thus it can be stated that further development is often not only dependent on forest management cooperatives themselves, but also influenced by other forest policy actors, e.g. administration and stakeholders (Feil et al. 2018; Selter et al. 2013).

In a similar vein, diverse studies dealing with FMCs have highlighted the importance of uncertainty for the development of FMCs. Additionally, it can be stated that there has been insufficient analysis of factors determining the further development of forest management cooperatives under uncertain conditions (cf. Lönnstedt 2014; Selter et al. 2013; Wippel 2014). This paper aims to fill this gap.

To answer the research objective mentioned above, the following research questions are pursued:

1 Which framework conditions and natural conditions are perceived by FMCs as relevant in an uncertain environment for their further development due to changes in the timber selling processes in Baden-Wuerttemberg?

2 Which actors, capabilities, constellations and interactions are highlighted by FMCs in Baden-Wuerttemberg influencing their development in an uncertain environment due to changes in the timber selling processes?

The following section will introduce the theoretical framework, comprising the ACI and path dependency that form the basis for the analysis. The process of data collection and analysis is presented as part of the material and methods section. Afterwards, empirical results are presented and discussed. Finally, the conclusions are highlighted. 


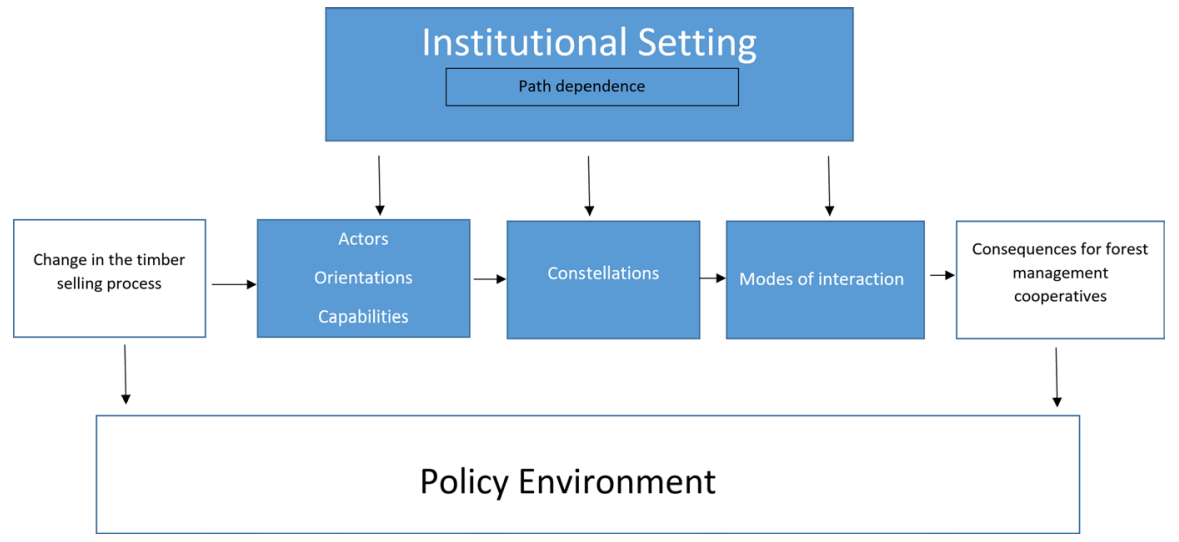

Fig. 1 Actor-centered institutionalism in connection with path dependency (cf. Scharpf 1997)

\section{Theoretical Framework}

This paper is based on a theoretical approach informed by "actor-centered institutionalism" (Mayntz and Scharpf 1995; Scharpf 1997) and complemented by the concept of path dependency (Fig. 1). This approach is used for the analysis of uncertainty because it provides the possibility to examine existing rules, societal norms and the capabilities of FMCs, that are relevant to reacting to uncertain conditions. Furthermore, the approach makes it possible to highlight the influence of other actors in an uncertain environment in the categories of constellations and interactions (cf. Mayntz and Scharpf 1995; Scharpf 1997).

ACI according to Scharpf “... conceptualizes policy processes driven by the interaction of individual and corporate actors endowed with certain capabilities and specific cognitive and normative orientations within a given institutional setting and within a given external situation" (Scharpf 1997, p. 37). The policy environment and the rules of society (North 1991) (institutional setting) thereby represent the "context of action" (Mayntz and Scharpf 1995, p. 43) that rational, corporative actors with their strategies and interactions (Scharpf 2000) have to deal with.

The actors' self-interests (orientations) can be characterized as "self-preservation, autonomy and growth" (Scharpf 1997, p. 64) that take place within a process of long-term development. The constellations consider strategies, which could also be influenced by the expectations of positions and the necessity to decide among preferences. All in all, strategies of the involved actors in different forms of actor constellations and with varied historical backgrounds are based on "capabilities ..., ... perception and evaluation of the outcomes obtainable, and the degree to which their payoff aspirations are compatible or incompatible with one another" (Scharpf 1997, p. 72).

Scharpf (1997) uses mixed-motive games to describe the ACI category "constellations" (Table 2). Assurance presupposes a clear interest of FMCs in cooperation and the anticipation of decisions by other potential cooperating partners, such as the sawmill industry or the forest administration. The Battle of Sexes game describes the 
situation in which one of the actors involved in the interaction first makes a proposal which benefits both, but the first proposer is the one who usually benefits more.

The modes of interaction category (Table 2) can be characterized by different forms (Scharpf 1997). These forms have a "significant effect on the outcomes of interactions in any given actor constellation" (Scharpf 1997, p. 89). Unilateral action is characterized by the maximization of one's own benefit. Rejecting decisions that are not in actors' self-interests is an element of this unilateral action. Negotiations are characterized by the "binding force of negotiated agreements" (Scharpf 1997, p. 116). This refers to agreements, oral or written, which are intended to contribute to the achievement of objectives. Hierarchical direction makes it possible to disregard preferences and thus to achieve results that are not in the self-interest of actors.

While the ACI framework takes up ideas of both historical institutionalismwhich focuses on events - and rational-choice institutionalism (Schimank 2007), events are considered only indirectly in the individual ACI categories. However, it is necessary to consider these events as they provide the initial impetus for far-reaching developments. To overcome this problem, the present study uses the concept of path dependency and the respective approach of Pierson (2000) to identify historical influences on the decision-making process. Thus, the ACI categories of policy environment, institutional setting, actors, constellations and modes of interaction are complemented by a historical perspective.

This historical perspective is considered using increasing returns as a basis. This means, self-strengthening effects are taken into account. These can occur if paths are followed over a long time. In this historical context, self-strengthening effects lead to an increase in transaction costs. These can hinder change towards different options (Pierson 2000). In contrast to other theories of path dependency, constellations of actors can also be considered (Beyer 2005; Pierson 2000).

To date, the ACI concept has been applied in research areas that concentrate more on non-forestry actors, such as water management (Feichtinger 2013), the role of the European Commission in the liberalization of Europe (Schmidt 1998) and the role of economic actors (Pleins 2008). However, a few studies in the area of forest policy have applied ACI in a forest context (Baycheva-Merger et al. 2018; Dobšinská et al. 2013; Hogl 2002; Salka 2002). So far, ACI has not been used to better understand the interplay of institutions, actors and their interactions of FMCs. Therefore, this paper adds a new perspective to other studies concerned with private forest owners and FCMs.

\section{Materials and Methods}

Although the existing problem of further development of FMCs is generally known, the specific factors under changing uncertain conditions has not been described so far. Therefore an explorative research design was chosen (Becker 1993). This enables a "precise exploration and description of a situation" (Döring and Bortz 2016, p. 192) using qualitative methods. 


\section{Data Collection}

Due to the decision of the Federal Competition Authority that was first implemented in the German federal state of Baden-Wuerttemberg, the resulting change in the timber selling process, and to identify factors that are perceived by FMCs in this federal state and determine their development, four regional conferences in Königsbronn (A), Freiburg i. Br. (B), Gegenbach (C) and Karlsruhe (D) with 140 participants of 104 forest management cooperatives and forest management associations (FMAs) in Baden-Württemberg took place in 2017 (Table 1). FMCs could be members of FMAs that take over the political representation of FMCs and private forest owners' interests by lobbying. All representatives of FMCs and FMAs in Baden-Württemberg were invited to participate but each participant could only attend one of the events. The participating board members were employed as representatives of FMCs and FMAs from 3 months to 20 years. In order to achieve the highest possible number and thus to gain a broad database, the conferences were located in south-west, north, west and east BadenWuerttemberg, thereby allowing for short travel times (Table 1). Furthermore, the regional structure of the FMCs in Baden-Wuerttemberg was taken into account (cf. Wippel 2014). Two-thirds of the FMCs in Baden-Württemberg have been represented in these events.

Verbatim field protocols were prepared as minutes of meeting by two minute taker as part of a systematic observation of these events. Systematic observations were chosen because information on the specific processes of further development, information about the organizations and existing relationships should be collected (Thierbach and Petschick 2014). The field protocols were based on questions that reflected the conceptual content of the ACI. The representatives had to answer the questions individually without any discussion. Discussions were possible in the breaks of the conferences. This format was chosen because we wanted to avoid influences of other FMCs and FMAs. The representatives of FMCs and FMAs agreed that the protocols may be used on an anonymous basis for research purposes.

The description of the situation of organizational developments with regard to political influences on particular FMCs and FMAs five years ago and at the date of the conferences, the desired position of the FMC in five years' time and FMC's demands on policymakers represent the complex of questions of the institutional setting. This was intended to reveal possible institutionalization and development paths (path dependency). The policy-environment category included questions about the structure of the organization, e.g. the size of the individual farms and the number of members. The category actors includes the complex of questions on business/service areas and the related business orientation of the FCMs. The aim was to understand the orientations (self-interests) of the individual actors, identify perceived factors and obtain information on capabilities. Necessary prerequisites for the development of FMCs and the querying of business areas form the complex of questions for the category constellations. This set of questions was intended to identify relationships and strategies. The ACI modes of interaction category was queried through questions about business partners. 


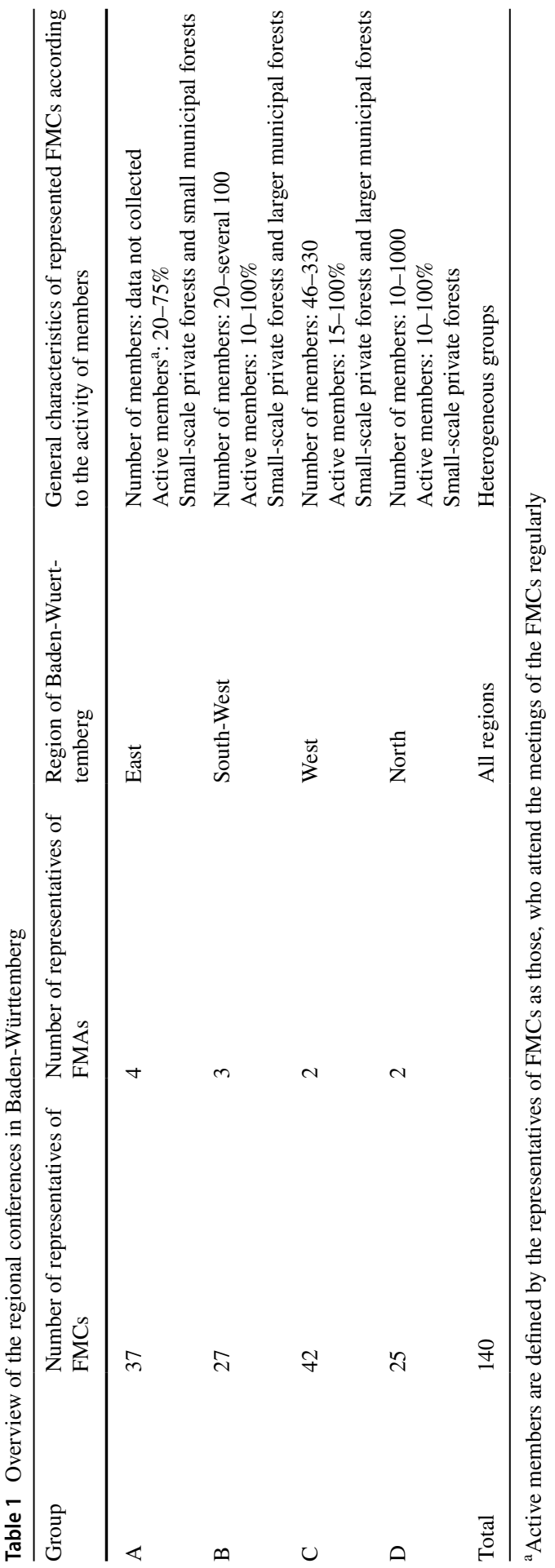


Table 2 Coding of field protocols by the theoretical terms of actor-centered institutionalism and path dependency by Mayntz and Scharpf (1995) and Scharpf (1997)

\begin{tabular}{|c|c|c|}
\hline Theoretical terminology & Theoretical content & Criteria for coding \\
\hline Institutional setting & Rules of society & $\begin{array}{l}\text { General conditions of FMC: } \\
\text { - Requirements to politicians and to FMC } \\
\text { themselves } \\
\text { - Developments in the last } 5 \text { years that } \\
\text { are non-economic and non-institutional } \\
\text { factors }\end{array}$ \\
\hline Policy environment & Natural environment & $\begin{array}{l}\text { Perceived environmental aspects of FMC: } \\
\text { - Infrastructure } \\
\text { - Natural conditions, } \\
\text { - Size of farmland and forest land } \\
\text { - Number of members }\end{array}$ \\
\hline Actors & $\begin{array}{l}\text { Collective and coop- } \\
\text { erative actors } \\
\text { Orientations/ Per- } \\
\text { ceptions } \\
\text { Capabilities }\end{array}$ & $\begin{array}{l}\text { - Self-interests of FMC } \\
\text { - Strengths of FMC } \\
\text { - Weaknesses of FMC } \\
\text { - See opportunities of FMC } \\
\text { - See threats of FMC }\end{array}$ \\
\hline Constellations & $\begin{array}{l}\text { Assurance } \\
\text { Battle of sexes }\end{array}$ & $\begin{array}{l}\text { - A clear interest in cooperation } \\
\text { - Mutual predictability in social Interactions } \\
\text { - Common interest in the coordination of } \\
\text { - Decisions or sequential decisions }\end{array}$ \\
\hline Modes of interaction & $\begin{array}{l}\text { Unilateral action } \\
\text { Negotiation } \\
\text { Hierarchical control }\end{array}$ & $\begin{array}{l}\text { - Ignorance of agreements } \\
\text { - Agreements } \\
\text { - Overriding preferences of actors }\end{array}$ \\
\hline Path dependency & Increasing returns & $\begin{array}{l}\text { - Historical events } \\
\text { - Presented developments }\end{array}$ \\
\hline
\end{tabular}

\section{Data Analysis}

To highlight the perceived factors of the representatives of FMCs, a "qualityoriented category-driven text analysis" (Mayring and Fenzel 2014) was chosen based on the content of the conceptual categories of the ACI (Table 2).

The analysis of the minutes of meeting was conducted with the qualitative content analysis software MAXQDA 2018 manually using the above-mentioned keywords and their synonyms relating to the ACI categories and path dependency.

\section{Empirical Results}

In the following section, data from the regional conferences in Baden-Wuerttemberg will be presented. Results of the representatives of FMAs are not considered due to the aim of this paper. For this purpose, categories of ACI will be used to examine the social (institutional setting) and natural (policy environment) influencing factors. Capabilities and strategies that are perceived as necessary for 
dealing with the uncertain conditions due to the change in the timber selling process will be presented in the actors category. Finally, constellations and interactions under uncertain conditions are presented.

Broad consensus with regard to the influential factors, which are presented in the following in the ACI categories, can be found in the different groups of regional conferences. The group-specific answers are presented in brackets.

\section{Institutional Setting-Lack of Legal Certainty and the Need for Support}

Framework conditions are perceived by the representatives of FMCs (B, D) as a basis for legal certainty in the timber selling process. However, the participating members of forest management cooperatives mention that this legal certainty did not exist in the former timber selling process and now poses a problem for the future development of forest management cooperatives (A, B). It is stated that a lack of legal certainty has led to a perceived uncertainty about future development opportunities of forest management cooperatives (A, B). Furthermore, board members identify faster decisions regarding framework conditions as a precondition for further developing FMCs. Representatives of FMCs state, that the market opening resulting from the withdrawal of the state forest administration in the area of private and municipal timber selling is regarded as positive for the development of FMCs (D).

On the one hand, some of the representatives of FMCs argue that former framework conditions including the administrative structure of the state forest administration and forest extension services were better suited to overcome uncertain conditions $(\mathrm{C}, \mathrm{D})$. On the other hand, representatives of FMCs argue that the opportunity for a further development of forest management cooperatives is inhibited because of the continued existence of unequal competitive structures (A, B, C, D).

The influence of an administrative reform is perceived negatively for the further development by the representatives of FMCs (A). However, it is noted that in some regions forest extension services have declined and thus new opportunities for development due to the withdrawal of the state in this field arises (A, C, D). Furthermore, the fee structure within the timber selling process by the state forest administration is considered by the representatives of FMCs to be non-transparent and unfair, which impede further developments (D). Therefore, participants request information on the actual full costs of timber sales and consulting services in order to create a level playing field for their further development (D).

In addition, representatives of FMCs perceive that demands on forestry have increased over the years and refuse being the only ones burdened with these. Accordingly, forest funding is regarded as very important for the development of FMCs (A, B, C, D). Financing of professionalization, concerning the general manager and his/her administration, are considered to be particularly vital for the further development of FMCs. Funding for timber mobilization as well as the construction and maintenance of forest roads are also considered important for further development (C). In addition, positive developments in funding for forests and the governmental pilot projects, which support the establishment of umbrella organizations, are highlighted for further development (D). However, the limited duration of forest 
support measures is perceived as counterproductive in this regard (A, D). Representatives of FMCs mention that general funding conditions should better meet their needs, e.g. forest services, and should be more reliable, because funding is essential for the development of FMCs (D).

Moreover, the analysis of the protocols highlights that the participants expect appropriate compensations for public welfare services in the future which in turn would be used for further development. However, EU rules for public funding and multiple responsibilities of the administration are considered to be burdensome for the further development of FMCs, because of the limited FMCs capabilities (see 4.3) (B, D).

\section{Policy Environment-Revenues of Timber, Fragmentation and Calamites as Aggravating Factors}

Representatives of FMCs highlight that some of the positive developments in FMCs result from high revenues from coniferous timber. In contrast, the poor market conditions for deciduous wood are perceived as a constraining influence. Representatives of FMCs emphasized that the small scale of highly fragmented forests (average of Baden-Wuerttemberg 2 ha) in some regions of Baden-Württemberg is regarded as a challenge for the further development of forest management cooperatives (A, D). In particular, the combination of deciduous and mainly small-scale forests is perceived as an inadequate condition for further development of FMCs (A). Calamities are perceived as providing an incentive to recruit new members and as highlighting the necessity of support provided by FMCs (A, B). Additionally, fundamental developments such as the existing age structure of members of forest management cooperatives and a related generational change are noted and emphasized as challenges for further development of FMCs (C, D).

\section{Forest Actors, Orientations, Capabilities and Perceptions of FMCs}

Actors perceived by the members of the board of forest management cooperatives as relevant for their work and the further development are FMCs, private and municipal forest owners, the state forest administration and sawmills.

Representatives of FMCs highlight, that district foresters and employees of the state forest administration are the most influential actors for the further development. Especially in highly fragmented areas the fundamental importance of state foresters is pointed out (A, B, D).

Furthermore, representatives of FMCs emphasize that the solidarity of members regarding cooperative timber selling represents an important self-interest of FMCs. It is argued that it enables them to strengthen their market positions and provides further development opportunities. Additionally, it is suggested that representation of owners' interests needs to be strengthened, so that a better representation of interests takes place. This improved representation of interests results in new development opportunities for member recruitment (C). 
The FMCs representatives pointed out that the that the capability to organize operational and strategic processes is important for further development. These capabilities include skills in entrepreneurship, market competence/meeting market requirements, communication skills and the acquisition of service support (A, B, C, D).

Most of the representatives of FMCs note that many of them are volunteers who have to possess each of the defined skills to initiate further developments. These capabilities are diverse and thus have to be considered in detail. On the one hand, representatives of FMCs perceive it as positive that volunteers are willing to take on the challenging work. On the other hand it is perceived partly as a problem for FMCs if volunteers reach their own limits when performing entrepreneurial services and taking on corresponding responsibilities, particularly in terms of their available time and expertise (C). If there is a perceived lack of capability with regard to market competence, sound knowledge of the current market price is also likely to be missing. Consequently, increasing uncertainty about too low timber selling prices emerges and results in an uncertainty about further development opportunities in terms of timber selling (A). Apart from price for timber and wood bundling (B, C, D), the changing supply of timber from members (D) is perceived as a challenging factor relating to market competence and developments in particular in cases where FMCs are selling the wood on their own. Representatives of FMCs argue that it is necessary to have reliable timber quantities available prior to timber selling negotiations in order to have better conditions and to generate revenue for further development steps. The uncertainty and limited timber quantities result from natural factors, e.g. calamities, but also from a changing situation in the sawmill industry, making it difficult to sell small quantities of timber on the market (B, D). FMCs emphasize that cooperatives which have only private forest owners as members can only partially, or not at all, meet the required timber sales volumes, meaning that they are not able to meet market demands and thus to develop further (C, D). Limited communication between individual members and the cooperatives $(C)$ are regarded as one of the reasons for this. This lack of communication skills is also perceived as a reason for the limited ability of FMCs to recruit enough members and thus provide the quantities of timber required by the market (C). Finally, the participating members mention that the ability to form umbrella organizations, which represent a further development opportunity for cooperative relationships and experience in the organization of operational and strategic processes, is rated as low (D).

According to the perception of forest management cooperatives, which highlighted that they have already been able to meet market requirements, direct access to the timber market is regarded as positive for the further development of timber selling. This is reinforced by the withdrawal of the state forest administration in some regions of Baden-Wuerttemberg. The withdrawal is perceived as a driver for further development of self-initiative and municipal cooperation (C). However, participating members mention that the behavior of the forest administration and its lack of will to create clear structures lead to uncertainty (A, B, D). Particularly timber selling offices that are part of the administration are perceived as competitors, that complicate further developments (A, B). In some regions, private forests are given significantly less consideration $(\mathrm{A}, \mathrm{C})$. Unequal conditions regarding the 
provision of advice and support by the forest state administration in the districts are noted and seen as obstacles for further developments (C). However, representatives of FMCs highlight that if a freedom of choice regarding the receipt of forest services is not considered in further political developments, this aspect for further developments will be perceived negatively. Basically, representatives of FMCs note that a demand for comprehensive service packages exists that supports development activities.

A general concern is expressed about the future viability of FMCs. The cooperatives' participating members mention that the positive evaluation of achievable results with regard to the future development will only happen if more autonomy in the form of independence from state structures and organizational development is achieved (C).

\section{Constellations and their Impact of the Development of FMCs}

Long-standing interactive relationships with state foresters and thus a certain dependence on this broad knowledge is highlighted as a noticeable development (A, $\mathrm{B}, \mathrm{C}, \mathrm{D})$. On the one hand, state foresters are perceived as partners that support the development of cooperative forest managements (A, B, C, D). On the other hand, representatives of FMCs noted that the protection of foresters' own interests is perceived as self-preservation and thus developments are impeded (B).

In this context, together with an expected withdrawal of state forest extension services, the representatives of FMCs emphasize the increasing importance of municipal foresters for the future development $(\mathrm{C}, \mathrm{D})$. In a variety of cases, good cooperation between municipal forest owners and FMCs is perceived (C, D). Representatives of FMCs also state that this cooperation leads to a regular and steady supply of timber to the market by the forest management cooperatives. Finally, representatives of FMCs conclude that the municipal forest is a partner that offers stability in the context of wood supply (D).

Participating members report that FMCs further develop their relationships to other FMCs in the case of low-value products to achieve a better market position $(B, C)$. Representatives of FMCs express an interest in the provision of large quantities of timber at the lowest price possible to the sawmill industry in order to further develop existing relationships even under uncertain conditions $(B, C)$.

\section{"Modes of Interaction"-Between Existing State Influence and Own Decision Making}

It is emphasized by the representatives of FMCs of the regional conferences A and $\mathrm{C}$, that the negotiating position is weakened and unsatisfactory due to rather small quantities of timber. They highlight, that this is exacerbated by insufficient information on timber prices due to the decisions of the Federal Competition Authority, which leads to uncertainty.

Representatives of FMCs highlight that some forest management cooperatives have decided to partly outsource their management to umbrella organizations. It is 
noted that these are controlled by FMCs themselves and are necessary for their further development (D).

Representatives of FMCs highlight that, for many years, their timber sales have been controlled by state foresters and thus further developments to overcome uncertain conditions were complicated because of the persistent strong influence of foresters (C). However, representatives of FMCs note that this changed in some cases as some state foresters decided that forest management cooperatives had to be independent (C). They state that some state foresters do not support the preferences of FMCs resulting from their interest in self-preservation of the state forest administration in its present administrative role (A, B, C, D). In those cases where foresters are still involved in the decision-making process through advice and services, it is possible that FMCs will veto respective decisions of state foresters. The veto right enables the FMCs to carry out preferred developments (C).

\section{Discussion}

This section deals with the theoretical interpretation and discussion of the empirical results highlighted by the participants of the regional conferences in 2017 and the resulting insights against the background of existing literature. Although the crucial legal issues in the timber sales process were completed in 2018 and the withdrawal of the state in the timber selling process was decided (Bundesgerichtshof 2018), making the FMCs' environment more secure and other questions, e.g. hardly any timber sales opportunities and low timber prices because of the beetle problem, for FMCs have become relevant, the associated factors for further developments of FMCs are still relevant in some regions of Baden-Wuerttemberg.

It is remarkable that not in all regional conferences the same results are emphasized by the representatives of FMCs. These differences can on the one hand be explained by the different structural and cultural areas in Baden-Wuerttemberg and on the other hand on the different organizational types of FMCs in Baden-Wuerttemberg and their abilities to face uncertain conditions (cf. Wippel 2011, 2014).

\section{Institutional Setting and Policy Environment-Framework Conditions}

Legal certainty, transparency in the cost structure and the dissolution of competing state organizations are considered essential for the development by FMCs in an uncertain environment. The decision of the Federal Competition Authority has created legal certainty but uncertainty cannot be avoided in general by valid resolutions, because binding characteristics such as contracts or resolutions, do not prevent uncertainty (Kieser and Ebers 2014). Due to the results of others (e.g. Quiroga et al. 2019; Sarvašová et al. 2014; Schaffner et al. 2009; Suda et al. 2009) uncertainty can be avoided by economic framework conditions that support FMCs in their development to professional organizations, e.g. forest subsidies. We expand these results and emphasized that also constellations and interactions are relevant factors beside the economic framework conditions to avoid uncertainty. 
Furthermore, the results highlight the challenge of fragmented forest ownership, e.g. small quantities of timber or problems with forest road construction, because permits are required from every forest owner, for the development under changing conditions. They thus confirm the importance of fragmentation in the existing literature (Angelova et al. 2009; Schraml 2012; Živojinović et al. 2015).

\section{Actors, Capabilities and Perceptions}

Other FMCs, private and municipal forest owners, the state forest administration, sawmills and district administrations are important actors for FMCs under (uncertain) conditions. These actors also have been emphasized by other authors (Lawrence et al. 2020; Rapp 2000; Schraml 2012; Schraml and Selter 2011; Selter et al. 2013; Stoettner and Ní Dhubháin 2019) to be influential for a further development of FMCs.

The capabilities that FMCs highlight to overcome uncertain conditions are skills in entrepreneurship, market competence/ meeting market requirements, communication skills and the acquisition of support. The results thus confirm the research of Kajanus et al. (2019; Lawrence et al. 2020; Schaffner et al. 2009; Suda et al. 2009), who point out the necessity for services. Kieser and Ebers (2014) emphasized that general societal requirements have increased over the last 20 years and organizations must take up and implement these requirements in order to survive.

Existing literature has always pointed out the importance of the state (Lawrence et al. 2020; Rapp 2000; Schaffner et al. 2009; Schraml 2012; Suda et al. 2009) when it comes to the management of privately owned forests. However, the results of this study show the perception that a withdrawal of the state forest administration is a driver of self-initiative to further development under uncertain conditions.

\section{Constellations}

The results point out that there is cooperation between state foresters and FMCs, municipal foresters and FMCs and FMCs with other FMCs in timber sales. These different constellations, including a clear interest in cooperation, can be described as "Assurance" (Scharpf 2000) because the results that are achieved, e.g. in the timber selling process, are positive for all involved. If timber is sold via the state timber sales offices, this can be understood as a "Battle of Sexes" (Scharpf 2000), because of an interest in coordinating joint decisions with benefits for both, forest administration as well as for the FMCs, but potentially higher benefits for the former. The factor of clear interest of cooperation between actors has thus a positive impact on further developments under uncertain conditions. Existing studies (Härdter 2003; Lawrence et al. 2020; Petkau 2007; Rapp 2000; Selter et al. 2013; Suda et al. 2009; Živojinović et al. 2015) have further developed this result, providing more detailed information about the existing constellations and their impact on the further development of FMCs, e.g. the preservation of existing long-term relationships based on a clear interest of cooperation. 


\section{Modes of Interaction}

The form of negotiation in which unsatisfactory results and uncertainty can be achieved due to lack of quantities of timber is to be regarded as "Distributives Bargaining" (Scharpf 2000) in the sense of the ACI, in which the costs and benefits of the negotiating partners between the forest management cooperative and sawmill industry are unequally distributed (Scharpf 2000).

The veto possibility can be seen as a unilateral action in terms of the ACI, because actions can be rejected in order to protect their own interests and thus to overcome uncertain conditions (Scharpf 2000).

The mentioned earlier control of timber distribution channels and the less consideration of preferences by the foresters and forest administration can be regarded as the ACI hierarchical control interaction form, because the preferences of the FMCs were rarely considered (Scharpf 2000).

The individual forms of interaction listed above can be seen as a broadening of the results of Kluvánková et al. (2018) and others (e.g. Nijnik et al. 2019; Van Wijk et al. 2018), which emphasize the importance of interactions for further developments. Forms of interaction are not only considered as relevant for the cooperation of actors, but also the specific forms of unilateral action and hierarchical control and their influence under uncertain conditions can be named.

\section{Conclusions}

The results using actor-centered institutionalism point out that framework conditions and the capabilities of actors determine developments under changing circumstances. The analysis of constellations and interactions provides results that represent important influencing factors for further developments. The research of constellations and the strategies underlying these constellations through game theory approaches seems promising according to the available results, because constellations and interactions are relevant for the development of FMCs and thus for organizations. Thus, more specific details that influence the development of an organization under (uncertain) conditions can be identified. We recommend the research on the different forms of constellations and interactions also in other research field, e.g. social innovation and interaction. In this way, it is not only possible to describe constellations and their effects on development, as has been the case up to now, but possible results are uncovered and explained by possible actions, strategies and the interests of the individual actors. In addition, the results on interactions highlight that the specific forms of unilateral action and hierarchical direction provide detailed results that are important for the development of FMCs. Thus, the results contribute in particular to the further development of organizations, especially under uncertain conditions. For future research, it is recommended that the constellations and interactions categories are investigated in greater depth with quantitative methods to verify the factors mentioned because this research is limited to the federal state of Baden-Wuerttemberg. The resolution of the Federal Competition Authority does not only influence the timber selling process in Baden-Wurttemberg but also in other 
federal states with other institutional settings. Thus, we recommend a German wide research with different institutional contexts and with regard to constellations and interactions.

We recommend FMCs to search actively for cooperation partners, such as municipal forest owners, to invest money in human resources, e.g. coaches, to avoid the limitation of capabilities and to exchange with other FMCs or enterprises ones a year in regional conferences and discuss there the future developments that are necessary to implement organizational structures that can avoid uncertainty. We recommend the state administration to maintain a constant exchange with FMCs to better translate needs into framework conditions.

Acknowledgements We appreciate Eva Mayr-Stihl foundation for their generous project funding.

Author Contributions Data collection (2017): AS, US; secondary analysis of the collected data (2018): MS; theoretical framework and methodology: MS, DK, AS; supervision: AS, DK, US; writing-original draft MS; writing-review and editing: AS, DK, US, project financing: Eva Mayr-Stihl Stiftung.

Funding Open Access funding enabled and organized by Projekt DEAL.

Open Access This article is licensed under a Creative Commons Attribution 4.0 International License, which permits use, sharing, adaptation, distribution and reproduction in any medium or format, as long as you give appropriate credit to the original author(s) and the source, provide a link to the Creative Commons licence, and indicate if changes were made. The images or other third party material in this article are included in the article's Creative Commons licence, unless indicated otherwise in a credit line to the material. If material is not included in the article's Creative Commons licence and your intended use is not permitted by statutory regulation or exceeds the permitted use, you will need to obtain permission directly from the copyright holder. To view a copy of this licence, visit http://creativecommons.org/licen ses/by/4.0/.

\section{References}

Angelova E, Irimie D, Sotirov M, Winkel G (2009) Bulgarien und Rumänien in der Europäischen Union-forstpolitische Herausforderungen [Bulgaria and Romania in the European Union-challenges for forest policy]. Swiss For J 160(1):15-22

Baycheva-Merger T, Sotirov M, Holmgren S, Selter A (2018) Institutional and actor-oriented factors constraining expert-based forest information exchange in Europe: a policy analysis from an actorcentered institutionalist approach. For 9(3):129

Becker FG (1993) Explorative forschung mittels bezugsrahmen-ein beitrag zur methodologie des entdeckungszusammenhangs. German journal of research in human resource management, empirische personalforschung. JSTOR, New York, pp 111-127

Beyer J (2005) Pfadabhängigkeit ist nicht gleich Pfadabhängigkeit!: Wider dem impliziten Konservatismus eines gängigen Konzepts. http://www.zfs-online.org/index.php/zfs/article/viewFile/1179/716. Accessed 18 Dec 2017

Bundesgerichtshof (2018) Beschluss KVR 38/17. http://juris.bundesgerichtshof.de/cgi-bin/rechtsprec hung/document.py?Gericht=bgh\&Art=en\&nr=85081\&pos=0\&anz=1. Accessed 10 Apr 2020

Bundeskartellamt (2008) Beschluss B2-90/01-4

Campbell M, Kittredge DB (1996) Ecosystem-based management on multiple NIPF ownership. J For 94(2):24-29

Dobšinská Z, Šálka J, Sarvašová Z, Lásková J (2013) Rural development policy in the context of actorcentred institutionalism. J For Sci. 59(1):34-40

Döring N, Bortz J (2016) Untersuchungsdesigns. In: Forschungsmethoden und evaluation in den sozial und humanwissenschaften. Wiesbaden, Springerverlag, p 5 
Feichtinger J (2013) Politischer wandel im gewässermanagement: die implementation der EU-wasserrahmenrichtlinie im spannungsfeld von wasserkraft und gewässerschutz in österreich und bayern. http:// www.partizipation.at/fileadmin/media_data/Downloads/Forschungsplattform/Dissertation_Feich tinger.pdf. Accessed 19 Feb 2018

Feil P, Neitzel C, Seintsch B, Dieter M (2018) Privatwaldeigentümer in deutschland: ergebnisse einer bundesweiten Telefonbefragung von Personen mit und ohne Waldeigentum. Landbauforsch Appl Agric For Res 68(3/4):87-130

Ficko A, Lidestav G, Ní Dhubháin Á, Karppinen H, Zivojinovic I, Westin K (2019) European private forest owner typologies: a review of methods and use. For Policy Econ 99:21-31

Gießen L, Hubo C, Krott M, Kaufer R (2013) Steuerungspotentiale von Zielen und Instrumenten des Politiksektors Forstwirtschaft und deren möglicher Beitrag zu einer nachhaltigen Entwicklung ländlicher Regionen. Zeitschrift für Umweltpolitik and Umweltrecht 36(3):261-291

Glück P, Avdibegović M, Čabaravdić A, Nonić D, Petrović N, Posavec S, Stojanovska M (2010) The preconditions for the formation of private forest owners' interest associations in the Western Balkan Region. For Policy Econ 12(4):250-263

Härdter U (2003) Nichtbäuerliche Eigentümer von Kleinprivatwald. Eine Untersuchung der "neuen" Eigentümerstruktur im Kontext gesellschaftlicher Entwicklungstrends. Dissertation

Hasel K (1985) Forstgeschichte-Ein Grundriß für Studium und Praxis, Pareys Studientexte 48, Hamburg und Berlin. Parey Verlag, Hamburg

Hogl K (2002) Reflections on inter-sectoral co-ordination in national forest programmes, Cross Sec Policy Imp For, 4-6

Hogl K, Pregernig M, Weiss G (2005) What is new about new forest owners? a typology of private forest ownership in Austria. Small-scale For Econ Manag Policy 4(3):325-342

Hugosson M, Ingemarson F (2004) Objectives and motivations of small-scale forest owners; theoretical modelling and qualitative assessment. Silva Fennica 38(2):217-231

Ingemarson F, Lindhagen A, Eriksson L (2006) A typology of small-scale private forest owners in Sweden. Scand J For Res 21:249-259

Kajanus M, Leban V, Glavonjić P, Krč J, Nedeljković J, Nonić D, Nybakk E, Posavec S, Riedl M, Teder M, Wilhelmsson E, Zālīte Z, Eskelinen T (2019) What can we learn from business models in the European forest sector: exploring the key elements of new business model designs. For Policy Econ 99:145-156

Kieser A, Ebers M (2014) Organisationstheorie, Stuttgart

Kittredge DB (2005) The coopertaion of private forest owners on scales larger than one individual property: international examples and potential application in the United States, Department of Natural Resources Conservation, University of Massachusetts. https://www.sciencedirect.com/science/artic le/pii/S1389934104000243

Kluvánková T, Brnkal'áková S, Špaček M, Slee B, Nijnik M, Valero D, Miller D, Bryce R, Kozová M, Polman N, Szabo T, Gežik V (2018) Understanding social innovation for the well-being of forest dependet communities: a preliminary theoretical framework. For Policy Econ 97(2018):163-174

Kronholm T (2016) How are Swedish forest owners' associations adapting to the needs of current and future members and their organizations. Small-scale For 15(4):413-432

Kuuluvainen J, Karppinen H, Hänninen H, Uusivuori J (2014) Effects of gender and length of land tenure on timber supply in Finland. J For Econ 20(4):363-379

Lawrence A, Deuffic P, Hujala T, Nichiforel L, Feliciano D, Jodlowski K, Lind T, Marchal D, Talkkari A, Teder M, Vilkriste L, Wilhelmsson E (2020) Extension, advice and knowledge systems for private forestry: understanding diversity and change across Europe. Land Use Policy 94:104522

Leinert S (1996) Weiterentwicklung von forstwirtschaftlichen Zusammenschlüssen zu Dienstleistungszentren, Studie im Auftrag der Arbeitsgemeinschaft Deutscher Waldbesitzerverbände (AGDW), Dreieich.

Lönnstedt L (2014) Swedish forest owners' associations: establishment and development after the 1970s. Small-scale For 13:219-235

Matilainen A, Koch M, Zivojinovic I, Lähdesmäki M, Lidestav G, Karppinen H, Didolot F, Jarsky V, Põllumäe P, Colson V, Hricova Z, Glavonjic P, Scriban RE (2019) Perceptions of ownership among new forest owners - a qualitative study in European context. For Policy Econ 99:43-51

Mayntz R, Scharpf FW (1995) Der Ansatz des akteurzentrierten Institutionalismus. Gesellschaftliche Selbstregelung und politische Steuerung. Verlag, Campus, pp 39-72

Moog M, Borchert H (1999) Kosten und Nutzen forstwirtschaftlicher Zusammenschlüsse'. Die Bedeutung forstwirtschaftlicher Zusammenschlüsse als Marktpartner: Herausforderungen und 
Entwicklungsmöglichkeiten. Forstwissenschaftliche Fakultät der Universität München, München, Frank, pp 1-20

Nijnik M, Secco L, Miller D, Melnykovych M (2019) Can social innovation make a difference to forestdependent communities? For Policy Econ 100(2019):207-213

North D (1991) Institutions, institutional change and economic performance. Cambridge University Press, Cambridge, MA.

Oesten G, Roeder A (2002) Management von Forstbetrieben. Freiburg und Tripstadt, Germany

Ottisch A (2001) Co-operative and common property forms of forest management regimes_Economies of scale for small scale forest holdings in Europe, In: Annual seminar of the Irish timber growers society, Dublin, 8 November 2001

Padgee A, Kim Y-S, Daugherty P (2006) What makes community forest management successfull: a metastudy from community forests throughout the world. Society Nat Res 19:33-52

Petkau A (2007) Zur Rundholzvermarktung aus dem Kleinprivatwald durch forstwirtschaftliche Zusammenschlüsse: Ein Literaturüberblick: Arbeitsbericht. Albert-Ludwigs-Universität Freiburg, Institut für Forstökonomie, pp 48-2007

Petkau A (2008) Erfolgspotentialentwicklung forstwirtschaftlicher Zusammenschlüsse durch Verbundbildung

Pierson P (2000) Increasing returns, path dependence, and the study of politics. Am Polit Sci Rev 94(2):251-267

Pleins H (2008) Reformblockaden in der Wirtschaftspolitik: Die Rolle von Wirtschaftsakteuren in Polen, Russland und der Ukraine

Quiroga S, Suarez C, Ficko A, Feliciano D, Bouriaud L, Brahic E, Deuffic P, Dobsinska Z, Jarsky V, Lawrence A, Nybakk E (2019) What influences European private forest owners' affinity for subsidies? For Policy Econ 99:136-144

Rapp P (2000) Die Kooperation in forstwirtschaftlichen Zusammenschlüssen: Eine Untersuchung am Beispiel der Forstbetriebsgemeinschaften in Baden-Württemberg

Ripatti P, Järveläinen V-P (1997) Forecasting structural changes in non-industrial private forest ownership in Finnland. Scand For Econ 36:215-230

Salka J (2002) Kooperationsbeziehungen im Fonds zur Förderung des Waldes der Slowakischen Republik, Allgemeine Forst und Jagdzeitung 173. Jahrgang Heft 7/8 Juli/August

Sarvašová Z, Zivojinovic I, Weiss G, Dobšinská Z, Drăgoi M, Gál J, Jarský V, Mizaraite D, Põllumäe P, Šálka J, Schiberna E, Šišák L, Wolfslehner B, Zalite Z (2014) Zalitis T (2014) Forest owners associations in the Central and Eastern European region. Small-scale For 14:217-232

Schaffner S, Suda M (1999) Anmerkungen zur strategischen Positionierung forstwirtschaftlicher Zusammenschlüsse aus forstpolitikwissenschaftlicher Sicht. Forstliche Forschungsberichte Nr, p 175

Schaffner S, Suda M, Huml G (2009) Zusammenschlüsse auf Erfolgskurs. Dynamische entwicklung trotz stürmischer Zeiten. LWF aktuell 70/2009

Scharpf FW (1997) Games real actors play actor-centered institutionalism in policy research. Routledge, UK

Scharpf FW (2000) Interaktionsformen: Akteurzentrierter Institutionalismus in der Politikforschung, Aus dem Amerikanischen Übersetzt von Treib O.

Schimank U (2007) Neoinstitutionalismus. In: Benz A, Luetz S, Schimank U, Simonis G (Hrsg.) Handbuch Governance theoretische grundlagen und empirische anwendungsfelder

Schmidt S (1998) Liberalisierung in Europa: Die Rolle der Europäischen Kommission, Schriften des Max-Planck-Instituts für Gesellschaftsforschung Köln,

Schraml U, Härdter U (2002) Urbanität von Waldbesitzern und von Personen ohne WaldeigentumFolgerungen aus einer Bevölkerungsbefragung in Deutschland. Allg Forst u J 7-8:140-146

Schraml U (2003) Expectations towards forestry: The influence of personal networks with forest owners. Urban For and Urban Greening 1(3):161-170

Schraml U (2005) Between legitimacy and efficiency: The development of forestry associations in Germany. Small-scale For Econ Manage Poli 4(3):251-267

Schraml U, Selter A (2011) Lessons learnt from commonly owned forests for the establishment of "new commons" in private forestry. In: forest commons-role model for sustainable local governance and forest management international workshop Burbach, Germany Booklet 22 of the State Forestry Administration series North Rhine-Westphalia

Schraml U (2012) Zwischen Markt und Staat-Neue Wege der Privatwald-Politik. Berichte Freiburger Forstliche Forschung, Heft 92:64-86 
Schurr C (2006) Zwischen Allmende und Anti-Allmende Eine Untersuchung zur Struktur und Strukturentwicklung des kleinflächigen privaten Waldeigentums unter den Bedingungen der gesellschaftlichen Transformation am Beispiel des Freistaates Sachsen.

Selter A, Hartebrodt C, Brandl H, Herbohn J (2009) A Critical comparison of typologies of smallscale forestry in baden-württemberg derived using single and multiple criteria. Small-scale For $8(1): 25-42$

Selter A, Hörnig T, Schraml U (2013) Pilotprojekte brauchen einen Piloten. Evaluation der Pilotprojekte zur direkten Förderung der Holzvermarktung und der Waldbewirtschaftung in Forstwirtschaftlichen Zusammenschlüssen Nordrhein-Westfalens. Arbeitsbericht 01/2013. Freiburg

Stoettner EM, Ní Dhubháin Á (2019) The social networks of Irish private forest owners: an exploratory study. For Policy Econ 99:68-76

Suda M, Warkotsch W (2002) Mit den forstwirtschaftlichen Zusammenschlüssen ins 21. Jahrhundert. AFZ Der Wald Nr. 1/2002, S. 6 ff.

Suda M, Schaffner S, Huml G (2009) Der Wandel als Motor: Veränderte Rahmenbedingungen als Herausforderung für die forstlichen Zusammenschlüsse. LWF Aktuell 70/2009. https://www.lwf. bayern.de/mam/cms04/service/dateien/a70-forstliche-zusammenschluesse-web.pdf. Accessed 12 Mar 2018

Thierbach C, Petschick G (2014) Beobachtungen. In: Bauer, N. und Blasius, J.(Hrsg.) Handbuch Methoden der empirischen Sozialforschung

Van Wijk J, Zietsma C, Dorado S, De Bakker FGA, Marti I (2018) Social innovation: integrating micro, meso, and macro level insights from institutional theory. Bus Soc 58(5):887-918

Wippel B (2011) Analyse und Weiterentwicklung regional ausgerichteter Strukturen der Kooperation, Beratung und Betreuung im Kleinprivatwald von Baden-Württemberg als Voraussetzung zur Verbesserung der Marktleistung. http://www.cluster-forstholz-bw.de/fileadmin/cluster/cluster_pdf/ Gutachten-Wertschoepfung-im-Kleinprivatwald.pdf

Wippel B (2014) Struktur und motive forstlicher Zusammenschlüsse in Baden-Württemberg, Freiburg, I.Br.

Živojinović I, Weiss G, Lidestav G, Feliciano D, Hujala T, Dobšinská Z, Lawrence A, Nybakk E, Quiroga S, Schraml U (2015) Forest Land Ownership Change inEurope. COST Action FP1201 FACESMAP Country Reports, Joint Volume. EFICEEC-EFISEE Research Report. University of Natural Resources and Life Sciences, Vienna(BOKU), Vienna (AT) Online publication

Publisher's Note Springer Nature remains neutral with regard to jurisdictional claims in published maps and institutional affiliations. 